\title{
REPRESENTAÇÕES HUMORÍSTICAS DE FHC E DE LULA NO JORNAL $O$ GLOBO (1995-2010)
}

\author{
Marilda Lopes Pinheiro Queluz ${ }^{1}$ \\ Ligia Carla Gabrielli Berto ${ }^{2}$
}

\begin{abstract}
RESUMO: O objetivo deste texto é propor uma reflexão sobre os mecanismos do humor gráfico presentes nas representações dos ex-presidentes do Brasil, Fernando Henrique Cardoso (FHC) e Luiz Inácio Lula da Silva (Lula), publicadas no jornal O Globo, entre 1995 e 2010, a partir do seu acervo digital. Os desdobramentos desses dois governos até hoje são visíveis no país e a narrativa histórica dos mandatos deles também pode ser lida através de charges que caricaturizaram ambos. Considera-se que a charge é um enunciado, ou seja, a materialidade de uma situação comunicativa que depende do momento histórico em que foi produzido e se transforma a cada leitura. Nas estratégias discursivas criadas por Aroeira e, principalmente, por Chico Caruso, percebe-se um diálogo entre a caricatura dos políticos e a linguagem das charges, o uso de metáforas visuais, paródias, intertextualidade e citações, e até mesmo narrativas sequenciadas dos quadrinhos. Na interpretação e na crítica dos acontecimentos da política brasileira os desenhistas buscaram inspiração e referências na arte, no cinema, nos fatos jornalísticos e na própria história da caricatura.
\end{abstract}

PALAVRAS-CHAVE: humor gráfico; caricatura; charge; FHC; Lula.

\section{HUMOROUS REPRESENTATIONS OF FHC AND LULA IN THE NEWSPAPER "O GLOBO"(1995-2010)}

\begin{abstract}
The aim of this text is to propose a reflection on the mechanisms of graphic humor present in the representations of the former presidents of Brazil, Fernando Henrique Cardoso (FHC) and Luiz Inácio Lula da Silva (Lula), published in the newspaper $O$ Globo (The Globe) between 1995 and 2010, gathered from its digital archive. The repercussions of these two governments are to this day visible in the country and the historical narrative of their mandates can also be read through political cartoons that caricatured both of them. We consider the political cartoon as an enunciate, that is, the materiality of a communicative situation that depends on the historical moment in which it was produced and it transforms itself at each reading. In the discursive strategies created by Aroeira and, especially, by Chico Caruso, we perceive a dialogue between the caricature of the politicians and the language of the political cartoons, the use of visual metaphors, parodies, intertextuality and citations, and even sequenced comic narratives. In the interpretation and critique of the events of Brazilian

\footnotetext{
1 Doutora em Comunicação e Semiótica pela Pontifícia Universidade Católica de São Paulo (PUC-SP). Professora e pesquisadora em História da Arte do Programa de Pós-Graduação em Tecnologia e Sociedade (PPGTE) da Universidade Tecnológica Federal do Paraná (UTFPR).

${ }^{2}$ Mestranda em Tecnologia e Sociedade pelo Programa de Pós-Graduação em Tecnologia e Sociedade (PPGTE) da Universidade Tecnológica Federal do Paraná (UTFPR).
} 
politics, the artists sought inspiration and references in art, in the cinema, in the journalistic facts and in the very history of caricature.

KEYWORDS: graphic humor; caricature; political cartoon; FHC; Lula.

\section{REPRESENTACIONES HUMORISTICAS DE FHC Y DE LULA EN EL DIARIO "O GLOBO" (1995-2010)}

RESUMEN: El objetivo del texto es proponer una reflexión sobre los mecanismos del humor gráfico presentes en las representaciones de los ex presidentes de Brasil, Fernando Henrique Cardoso (FHC) y Luiz Inácio Lula da Silva (Lula), publicadas en el diario O Globo, entre 1995 y 2010, a partir de su acervo digital. Los desdoblamientos de estos dos gobiernos hasta hoy son visibles en el país y la narración histórica de sus mandatos también puede ser leída através de caricaturas que caricaturizaron ambos. Se considera que la charge es un enunciado, o sea, la materialidad de una situación comunicativa que depende del momento histórico en que fue producido y se transforma en cada lectura. En las estrategias discursivas creadas por Aroeira y, principalmente, por Chico Caruso, se percibe un diálogo entre la caricatura de los políticos y el lenguaje de las caricaturas, el uso de metáforas visuales, parodias, intertextualidad y citas, e incluso narrativas secuenciadas de los cómics. En la interpretación y en la crítica de los acontecimientos de la política brasileña los diseñadores buscaron inspiración y referencias en el arte, en el cine, en los hechos periodísticos y en la propia historia de la caricatura.

PALABRAS CLAVE: humor gráfico; caricatura; charge; FHC; Lula.

\section{INTRODUÇÃO}

O contexto político foi um dos principais alvos dos caricaturistas na imprensa brasileira desde o século XIX. A presença de caricaturas e charges nos periódicos impressos mostrou-se, especialmente a partir de 1870, um rico e complexo espaço de disputas, tensionamentos, críticas, visões de mundo e posicionamentos político-ideológicos, observados em momentos emblemáticos como as campanhas abolicionistas e republicanas, por exemplo. A tradição de charges e caricaturas se intensificou com as críticas feitas às autoridades e aos personagens eminentes da história, o que também contribuiu para transformar as publicações em poderosas armas de combate e instrumentos para a formação da opinião pública. O estudo das charges traz um outro registro da história política, diferente da oficial, construído 
paralelamente através do humor. Por outro lado, as charges eram interpretações, comentários sobre as notícias, aliando-se à própria história do jornalismo impresso.

O objetivo deste texto é refletir sobre as representações e os mecanismos do humor gráfico presentes nas caricaturas e charges referentes a dois políticos que passaram pela presidência do Brasil, Fernando Henrique Cardoso e Luiz Inácio Lula da Silva, publicadas no jornal O Globo ${ }^{3}$, entre 1995 e 2010, a partir do seu acervo digital. O foco temático foram as sátiras voltadas para a política envolvendo, especialmente, as principais medidas econômicas de cada governante.

Representações estão ligadas a estratégias e práticas sociais que se constituem como uma arena de disputas, em meio às tensões e contradições da sociedade. As representações não são neutras, estão "sempre colocadas num campo de concorrências e de competições cujos desafios sse enunciam em termos de poder e de dominação" (CHARTIER, 1988, p.17).

Elias Thomé Saliba (2002) considera a representação humorística uma forma privilegiada de representar a história, pois, explora a ambivalência da linguagem e propõe olhares alternativos para os discursos e as narrativas sobre o país. O autor chama a atenção para os diferentes contextos culturais que forjam representações humorísticas peculiares, metáforas visuais e verbais específicas, tipos e estereótipos concisos, repletos de subentendidos, silêncios e omissões.

\section{HUMOR GRÁFICO}

Já no clássico estudo sobre a caricatura brasileira, Herman Lima (1963) ressaltava a política como um dos temas preferidos dos nossos desenhistas. Renato Lemos (2001) destaca o fato de que desde as primeiras charges/caricaturas divulgadas nos periódicos brasileiros, especialmente a partir de 1840, os traços fazem rir ou lamentar enredos e contribuem para contar a história política do Brasil.

\footnotetext{
${ }^{3} \mathrm{O}$ jornal $O$ Globo, pertencente ao poderoso grupo de comunicação Organizações Globo, que além de diversos periódicos impressos em diferentes estados brasileiros, engloba emissoras de rádios, um portal de notícias e entretenimento, além da emissora de televisão com maior audiência do país. O periódico diário foi fundado em 29 de julho de 1925, por Irineu Marinho e destacou-se como um dos jornais de maior tiragem do país. A visão do seu conselho editorial, composto por membros da família Marinho, é de uma política conservadora.
} 
Existem diferentes modos de entendimento do desenho de humor. Para Joaquim Fonseca (1999), o humor gráfico é um conceito amplo que se define como a linguagem que contribui para que se faça uma leitura crítica dos acontecimentos, principalmente da política brasileira, envolvendo caricaturas, charges, cartuns, quadrinhos. Para este autor, a caricatura é um guarda-chuva que abrigaria os demais estilos. Pedro Lago (1999) também sublinha o caráter abrangente do termo caricatura e a complexidade em encontrar uma nítida distinção entre caricatura, charge e cartum, uma vez que os artistas transitam por estas áreas. Luciano Magno (2012, p. 15) afirma que, no Brasil:

[...] historicamente, a palavra caricatura, em sua concepção moderna, que é caracterizar, ganhou uma significação particular, se tornando o termo abrangente para todos os segmentos dessa arte, englobando a caricatura pessoal (portrait-charge), a charge (do francês charger, de carga, crítica) e o cartum (de temática mais universal).

A caricatura possui algumas características mais específicas de composição, sendo criada a partir de certos exageros, deformações, estilos pessoais de traço, carregando o toque de humor e de ironia em relação ao personagem representado. É atravessada por fatores culturais e mesmo ideológicos, tanto do autor quanto do jornal em que foi veiculada, e ainda passa pelas influências do contexto e do repertório dos quais o leitor parte para a construção de uma interpretação.

A caricatura foi "um termo genérico aplicado a todos os desenhos humorísticos, que pudessem provocar risos, críticas escancaradas e uma sátira demarcada” (RIANI, 2002, p. 25), e é pensada neste trabalho como uma categoria dentro do humor gráfico. No caso específico de nosso levantamento, observamos uma profunda interação entre a caricatura dos políticos e a linguagem das charges e até mesmo dos quadrinhos.

Para Romualdo (2000), "a charge é um texto visual humorístico que critica uma personagem, fato ou acontecimento político específico", e se enriquece no diálogo com a caricatura:

A charge [...] por focalizar uma realidade específica, ela se prende mais ao momento, tendo, portanto, uma limitação temporal. [...] A caricatura será compreendida como o desenho que exagera propositadamente as características marcantes de um indivíduo. [...] a charge e a caricatura não são excludentes. A caricatura, compreendida de acordo com esse conceito particularizado, aparece, com freqüência, como um elemento constituinte das charges (ROMUALDO, 2000, p. 33). 
No Brasil, o discurso político foi reforçado com as charges que destacavam a caricatura da fisionomia desses personagens nos jornais (MOTTA, 2006), provocando o riso, a reflexão da sátira ou mesmo do peso da crítica que contribuem para o reforço dessa leitura. Nas charges pesquisadas, a maior parte dos exemplos ressalta os traços marcantes dos personagens, baseados muito mais nas características físicas, expressões faciais e gestuais de FHC e Lula do que nos fatos jornalísticos. A semelhança se constitui por equivalência à referência que se tem do indivíduo e o conjunto dessas expressões torna-se uma manifestação crítica e humorística (FONSECA, 1999).

Para entender o contexto no qual a crítica está inserida é necessário ter conhecimento sobre o fato, o personagem ou a referência ilustrada. Para que o efeito humorístico da caricatura aconteça é importante que o repertório e o conteúdo ironizado sejam compartilhados pelos leitores. Nesse sentido, o leitor atua em cumplicidade e co-autoria do desenho de humor.

A charge é um enunciado. Bakhtin (2003, p. 274) definia enunciado como "a real unidade da comunicação discursiva", a materialidade de uma situação comunicativa que depende do momento histórico em que foi produzida e se transforma a cada leitura. $\mathrm{O}$ enunciado é uma resposta atravessada por várias vozes sociais e práticas culturais, no qual o indivíduo se constrói dialogicamente (FARACO, 2003). Portanto, analisar uma charge seria compreender as diversas camadas que imprimem significados individuais ou coletivos e que nos levam a uma compreensão do que se vê ou lê.

A charge não precisa, necessariamente, levar ao riso, ela pode provocar deslocamentos, reflexões críticas, outras visões de mundo, outras maneiras de dar sentido à realidade diária:

O surgimento do desenho de humor permitiu maior aproximação das classes subalternas em relação à política. A caricatura ajuda a traduzir os eventos, conflitos e grandes personagens políticos para a linguagem popular, tornando tais temas mais palatáveis para indivíduos iletrados e / ou socialmente excluídos. Ela contribui para desmistificar e dessacralizar o poder, mostrando líderes e chefes de Estado como seres humanos falíveis e, eventualmente, ridículos (MOTTA, 2006. p. 18). 
No contexto jornalístico, a charge constituiu-se como aliada do discurso editorial e funcionava, desde o início, como crônica política. A charge consegue traduzir, direta ou indiretamente uma opinião, tornando-a acessível aos leitores (MOTTA, 2006).

\section{FHC E LULA ENTRE METÁFORAS, PARÓDIAS E INTERTEXTUALIDADES}

Oito anos separam dois momentos marcantes da história política recente do Brasil: os primeiros mandatos dos ex-presidentes Fernando Henrique Cardoso (FHC), em 1995, e de Luiz Inácio Lula da Silva (Lula), em 2003. Os desdobramentos desses dois governos até hoje são visíveis no país e a narrativa histórica dos mandatos deles também pode ser lida através de charges que caricaturizaram ambos.

FHC representava o Partido da Social Democracia Brasileira (PSDB), alinhado à direita política, cuja proposta econômica caracteriza-se pelo neoliberalismo, assim como o Partido dos Trabalhadores (PT) e Lula estão associados ao projeto econômico do neodesenvolvimentismo, alinhados ao espectro político da esquerda no Brasil.

A vertente neoliberal, adotada por FHC, convergiu para a internacionalização da economia, permitindo a fragmentação dos processos da indústria e facilitando para que as grandes empresas transnacionais utilizassem as normas do livre-comércio e as baixas taxas, sempre de modo a lhes favorecer através da globalização financeira (KATZ, 2016). Sobretudo, no segundo mandato de FHC foram constituídos os parâmetros da gestão macroeconômica neoliberal da economia através do tripé: metas de inflação, câmbio flexível e superávit primário, vigentes mesmo nos governos posteriores (ALVES, 2014).

O neodesenvolvimentismo adotado no governo Lula é considerado um novo modo de desenvolvimento capitalista na era globalizada sob a dominância do capital financeiro. Segundo Alves (2014), o Brasil firmou o modelo com apoio político da burguesia interna do país que, beneficada pelos financiamentos do Estado através do Banco Nacional de Desenvolvimento (BNDES) para exportar seus produtos, fomentou as condições internas que, por outro lado, atingiram as camadas organizadas da classe operária e os setores populares com a redução do desemprego e a formalização do mercado de trabalho, oferta de crédito para dinamizar o mercado interno; aumento do gasto público nas políticas de transferência de renda via programas sociais. 
No projeto neodesenvolvimentista de Lula, Katz (2016) reconhece avanços, principalmente sociais: recuperação de salários, aumentos reais nas negociações, maior financiamento educativo e os beneficiários do Bolsa Família, numa fatia considerável de assistidos. Por outro lado, o autor avalia que os camponeses foram afetados pela concentração de terra e considera que a "diminuição da desigualdade foi muito limitada em um país onde $10 \%$ da população detém $75 \%$ da riqueza" (KATZ, 2016, p. 206).

É interessante perceber como a diferença entre os dois governos foi visualmente materializada nas charges referentes à posse de FHC (figura 1) e de Lula (figura 2).

Figura 01: Chico Caruso. Charge da posse de FHC

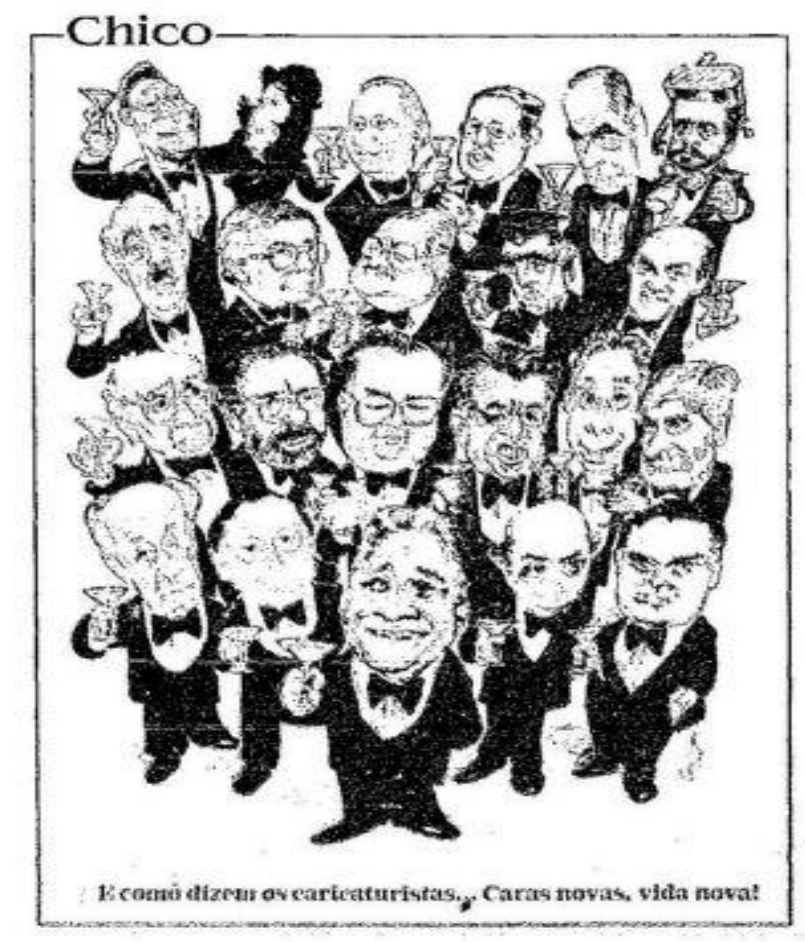

Fonte: $O$ Globo. 01.01.1995. www.acervo.oglobo.com.br

A figura 01, referente ao dia da posse de FHC, mostra-nos o tom da representação do início do governo. A ênfase no traje de gala e nas taças erguidas para o brinde constrói um ar de sofisticação e evoca a associação com as classes dominantes. A frase "E como dizem os caricaturistas...Caras novas, vida nova!” ironiza o próprio fazer do caricaturista e a hipótese de que o novo governo será diferente. A sátira está no fato de que os outros personagens além 
de FHC já são velhos conhecidos do público brasileiro. Para se nominar apenas alguns, está Pedro Malan ao lado direito de FHC, Ministro da Fazenda e José Serra, ao lado esquerdo, que seria o Ministro do Planejamento. Ambos também serão figuras constantes nas caricaturas, até porque eram considerados os homens fortes da economia. A expressão facial de FHC também indica que nem ele parece acreditar na proposta que o grupo de ministros representaria, pois a expressão das sobrancelhas deixa o riso dele um tanto incrédulo.

Figura 02: Chico. Charge da posse de Lula

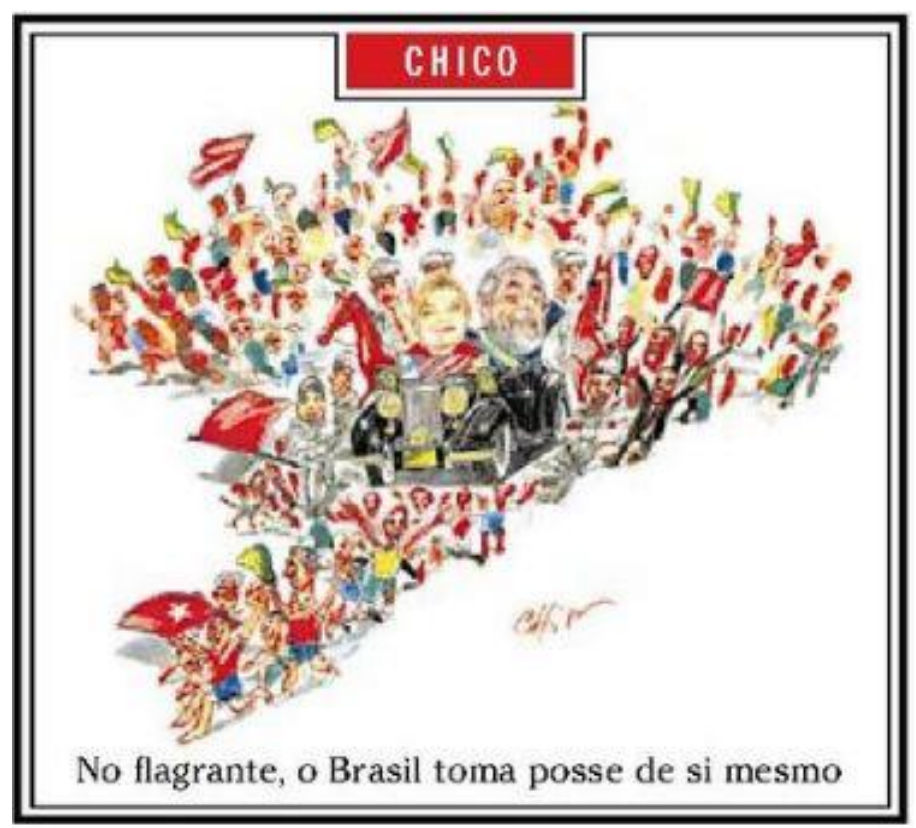

Fonte: $O$ Globo em 02.01.2003. www.acervo.oglobo.com.br

A posse de Lula (Figura 2) foi representada como uma continuidade da campanha política, investindo na ideia de que um homem da classe trabalhadora, um operário, assumia o cargo mais importante do país, presente tanto no signo visual quanto no verbal. A frase "No flagrante, o Brasil toma posse de si mesmo" parece sugerir que, naquele instante específico, todos os trabalhadores se sentiam fazendo parte do governo e da construção do país, delineando um mapa com diversidade de gênero, raça e etnia, classe. Reitera-se a ideia de proximidade entre os brasileiros e aquele que seria o representante das classes populares. A 
cor vermelha em evidência demarca o Partido dos Trabalhadores (PT) e tem sido, geralmente, um símbolo dos partidos de oposição, da esquerda ${ }^{4}$.

É possível fazer uma comparação com a crítica feita aos ministros de FHC na figura 01, comemorando com velhos políticos, enquanto Lula comemora com o povo, com o Brasil inteiro, que agora é vermelho. A expressão corporal, os gestos de Lula e sua esposa, Marisa, denotam muita emoção.

Os traços geralmente carregados para indicar a expressão facial, ou como reforço de contornos físicos dos personagens, sempre auxiliam a nortear a leitura. As caricaturas ajudam a coroar, destronar ou mesmo reforçar mensagens sobre os personagens. A linguagem visual bem-humorada e acessível oferece uma chance para a participação mais próxima da vida política através do deboche, o que contribui para diminuir a distância entre poderosos e cidadãos comuns e ainda ironiza o poder que se afere aos políticos (FIORIN, 2006).

Figura 03: Aroeira

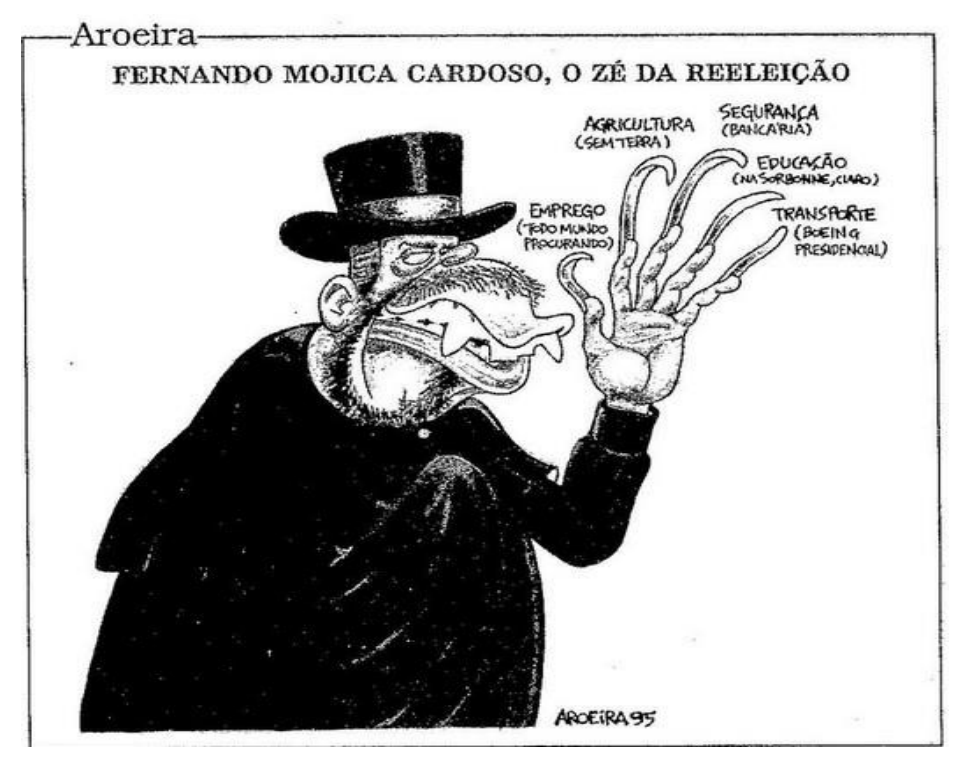

Fonte: $O$ Globo. 16.11.1995. www.acervo.oglobo.com.br

\footnotetext{
${ }^{4} \mathrm{Na}$ história política, a cor vermelha foi associada às bandeiras de revolucionários ligados à Comuna de Paris, em 1871, sob a influência de Karl Marx. Giannotti (2007) descreve que, antes disso, em 1845 os trabalhadores (conhecido como proletários, aqueles que possuem proles - filhos) haviam se unido à burguesia para lutar pela redução jornada de trabalho. Mas, a burguesia teria se aliado aos proletários apenas pela necessidade de mais tarde usar a força dos trabalhadores para derrotar o rei e a nobreza, que tinham voltado ao poder após o fim do ciclo da grande Revolução Francesa. No confronto entre proletários e burgueses, milhares de trabalhadores foram fuzilados e outros deportados de Londres. Num "verdadeiro banho de sangue, bandeiras ensanguentadas passaram a aparecer nas mãos dos trabalhadores. Este foi o começo da utilização de uma bandeira vermelha como símbolo da luta operários" (GIANNOTTI, 2007, p. 32).
} 
FHC estava no primeiro ano do primeiro mandato e a proposta de aprovar uma lei para autorizar a reeleição entrava em debate. Aroeira retoma o visual de um personagem conhecido dos brasileiros, "Zé do Caixão", e reitera essa relação no título da caricatura "Zé Mojica Cardoso, o Zé da Reeleição". Na imagem (figura 3), FHC tem os traços do rosto bastante exagerados, grotescos, com os dentes saltando da boca, o olhar desconfiado, indicando que ele está prestes a agir, com elementos que remetem ao Zé do Caixão, como a vestimenta, a barba, o chapéu e as longas unhas. A mão erguida com os cinco dedos bem abertos faz referência às cinco propostas usadas na campanha, no caso de uma possível reeleição. Um deles cita, de forma irônica, que entre as intenções está a de oferecer emprego, mas a frase "emprego todo mundo procurando", indica que a situação do país não é confortável e até o presidente quer o emprego por mais tempo. A proposta para "agricultura" revela o desprezo pelo tema, já que na ironia "sem terra" está a alegação constante do governo para protelar ações da reforma agrária. No terceiro dedo, ou na terceira proposta, "segurança", o subtítulo "bancária" faz uma menção que reforça o programa político do sistema que FHC representa, a segurança para transações econômicas dos ricos, afortunados e grandes empresários. A quarta proposta, "educação", resumida a "um sobrenome, claro", evoca as redes de influências, o acesso assimétrico a uma formação adequada. Por quinta proposta aparece o "transporte", o "boeing presidencial", longe das necessidades dos brasileiros, a garantia de transporte é apenas para o próprio presidente. Estas ironias, críticas e zombarias dão um sentido grotesco à figura de FHC, com um ar de mistério e terror, acentuando o caráter individualista das classes dominantes, mas só funciona se o público souber quem é Zé do Caixão e estiver por dentro dos debates políticos.

\footnotetext{
5 José Mojica Marins (1936) é um cineasta brasileiro que se apresenta geralmente com o figurino de seu personagem mais conhecido, Zé do Caixão, que surgiu pela primeira vez no filme À Meia-Noite Levarei Sua Alma, de 1963, caracterizado pelas roupas pretas alusivas à morte, já que é um agente funerário. Ele visitou o presidente Fernando Henrique Cardoso na semana em que a caricatura foi publicada.
} 
Figura 04: Aroeira

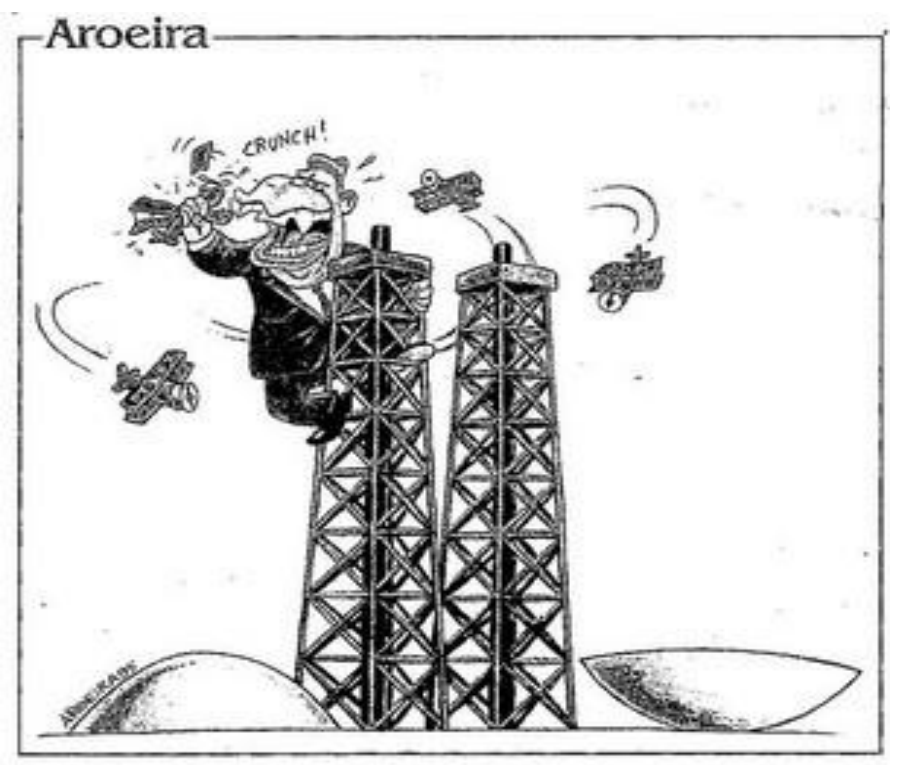

Fonte: O Globo. 07/06/1995. www.acervo.oglobo.com.br

Outra referência ao cinema aparece na figura 04. São diversas "camadas" que podem ajudar na leitura desta charge. Inicialmente, a mais forte associação remete a uma das cenas emblemáticas do filme King Kong ${ }^{6}$. A caricatura de FHC acentua traços animalescos, associando-o ao gorila King Kong, em defesa do fim do monopólio da Petrobrás. O desenho de Aroeira tende a investir em uma imagem estereotipada de FHC, colocando-o como um elemento assustador, descontrolado como a fera acuada. A estatal está representada pelas torres que analogamente formam plataformas de extração de petróleo e, ao mesmo tempo, compõem a fachada do Congresso Nacional, junto com as cúpulas nas laterais. $\mathrm{O}$ assunto em destaque no dia da publicação é a véspera da votação da emenda constitucional que pede o fim da atuação exclusiva da Petrobrás no setor petroleiro.

\footnotetext{
${ }^{6}$ King Kong possui muitas versões no cinema, deste a primeira, feita em 1933. Uma das refilmagens que ganhou destaque foi a de 1976, dirigida por John Guillermin, com a atuação de Jessica Lange e de Jeff Bridges. Ganhou o Oscar pelos efeitos especiais, principalmente numa das cenas mais conhecidas e reproduzidas da história, aparecendo até em desenhos infantis e comédias, o momento em que o gorila gigante escala as famosas Torres Gêmeas e é atacado por helicópteros (nas versões de 1933 e de 2005 a cena se passa no Empire State Building e o animal é atacado por aviões da força aérea).
} 
Fronteiras: Revista de História

Representações humorísticas de FHC e de Lula no jornal O Globo (1995-2010)

Marilda Lopes Pinheiro Queluz; Ligia Carla Gabrielli Berto

Figura 05: Chico. Estátuas

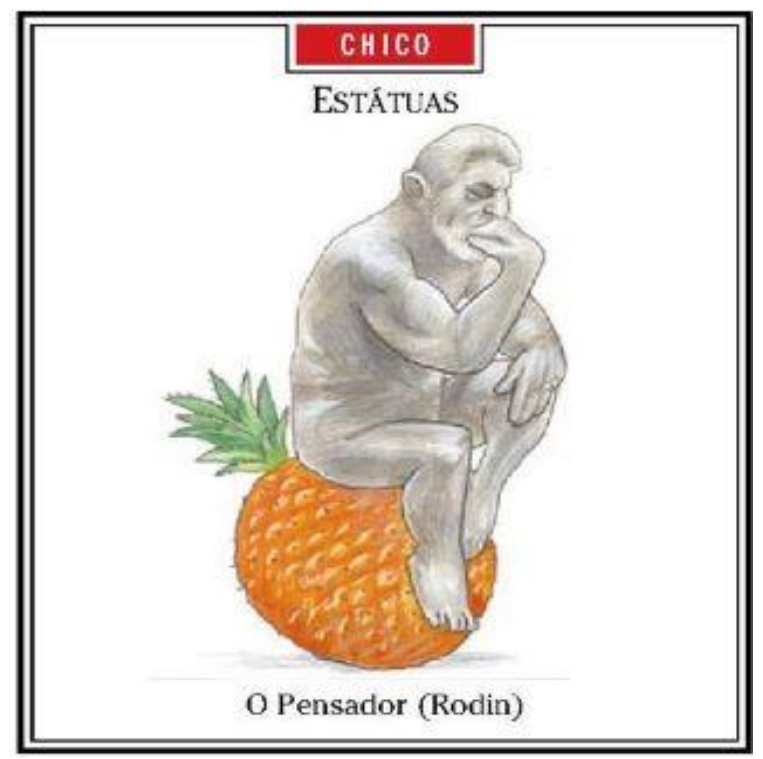

Fonte: $O$ Globo. 22.12.2003. www.acervo.oglobo.com.br

Uma das metáforas mais recorrentes para descrever o país ou o ato de governar o Brasil é o abacaxi, especialmente em relação à economia. Popularmente, costuma-se comparar problemas de difícil solução ao ato de descascar um abacaxi, fruta com casca grossa, repleta de espinhos e que, no caso da figura 05, representa os problemas do país que estariam perturbando os pensamentos de Lula. Este aparece como um homem concentrado, em reflexão, preocupado, como apontam as linhas definidas em sua testa. Trata-se de uma alusão à famosa escultura $O$ Pensador, do francês Auguste Rodin ${ }^{7}$. No contexto da época, Lula encerra o primeiro ano de governo com contradições políticas: expulsou aliados antigos do PT e se uniu a conservadores econômicos ligados ao PSDB, partido de oposição.

A paródia é um dos recursos mais utilizados nas charges, a partir de uma analogia do conceito perpassado para a linguagem visual. A produção caricaturizada é proposital para que uma imitação acentuada ressalte as diferenças entre a referência e a paródia. Para entender o contexto, o leitor precisa resgatar sua memória e conhecimentos acumulados. “A paródia é

\footnotetext{
${ }^{7}$ Auguste Rodin (1840-1917) foi um escultor francês que se notabilizou pela forte expressividade que imprimiu ao corpo humano nu. Originalmente, $O$ Pensador (1880) foi concebida como parte de uma encomenda para um museu de artes decorativas de Paris, Os portões do Inferno, inspirada em personagens da Divina Comédia, de Dante. Como o museu não foi construído, essa escultura se tornou uma obra independente (FARTHING, 2011).
} 
uma imitação de um texto ou de um estilo que procura desqualificar o que está sendo imitado, ridicularizá-lo, negá-lo" (FIORIN, 2006, p. 42).

Os casos de paródia ainda podem ser considerados exemplos de intertextualidade, pois contêm particularidades textuais e também são da ordem da manifestação, da materialidade (FIORIN, 2006).

O uso de intertextualidade para Bakhtin poderia ser ainda a denominação de um tipo composiconal de dialogismo: um texto no interior do outro texto, como um encontro de duas materialidades linguísticas, de modo que existam os dois textos, com independência um do outro (FIORIN, 2006).

Figura 06: Chico. Momento Poético: Da Silva em Pessoa

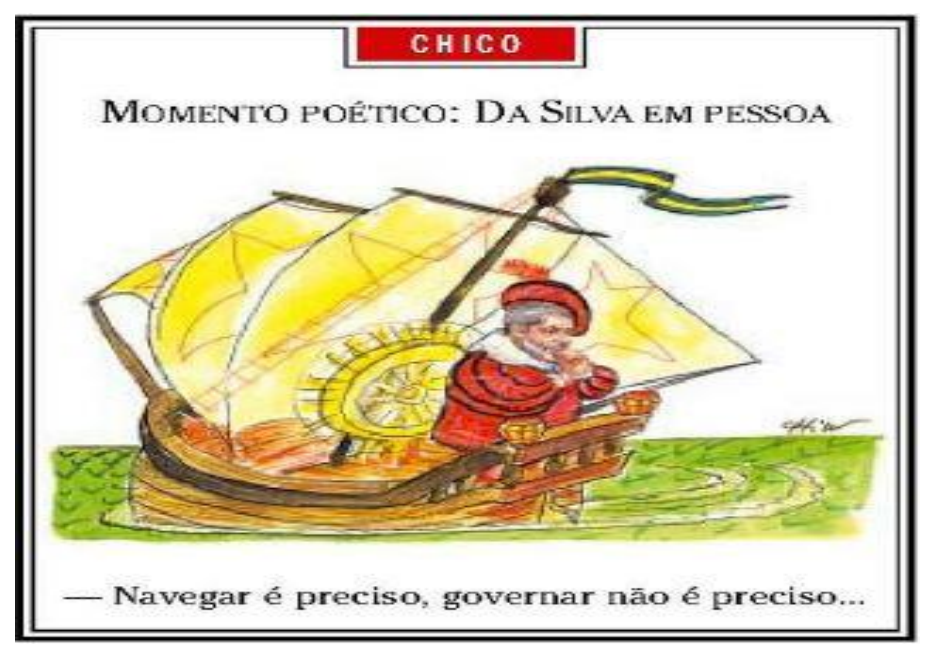

Fonte: $O$ Globo. 11.10.05. www.acervo.oglobo.com.br

A figura 06 é um um bom exemplo de paródia, um enunciado repleto de intertextualidades e expressões de linguagem. A cena evoca o período das grandes navegações portuguesas. A roupa que Lula usa faz menção aos trajes tradicionais das cenas que nos mostram navegadores como Vasco da Gama, assim como a embarcação remete às caravelas utilizadas nas viagens das comitivas portuguesas que desbravaram mares no século XV. A crítica, intertextual, porém, é relativa às viagens de Lula durante o primeiro mandato, associando as atividades de governar o país e viajar. O balanço da Presidência da República ao fim do segundo mandato de Lula, em 2010, indicou que ele fez 252 viagens ao exterior em oito anos de governo e esteve em 84 países. Cerca de metade delas foi realizada já nos 
primeiros quatro anos de governo, o que motivou essa paródia do chargista. $\mathrm{O}$ autor provoca relações de intertextualidade com a frase do poeta Fernando Pessoa, "Navegar é preciso, viver não é preciso", brincando com a adaptação que já se inscreve no título: "Da Silva em Pessoa", ou seja, a constatação de Lula de que "Navegar é preciso, governar não é preciso".

Figura 07: Chico Caruso

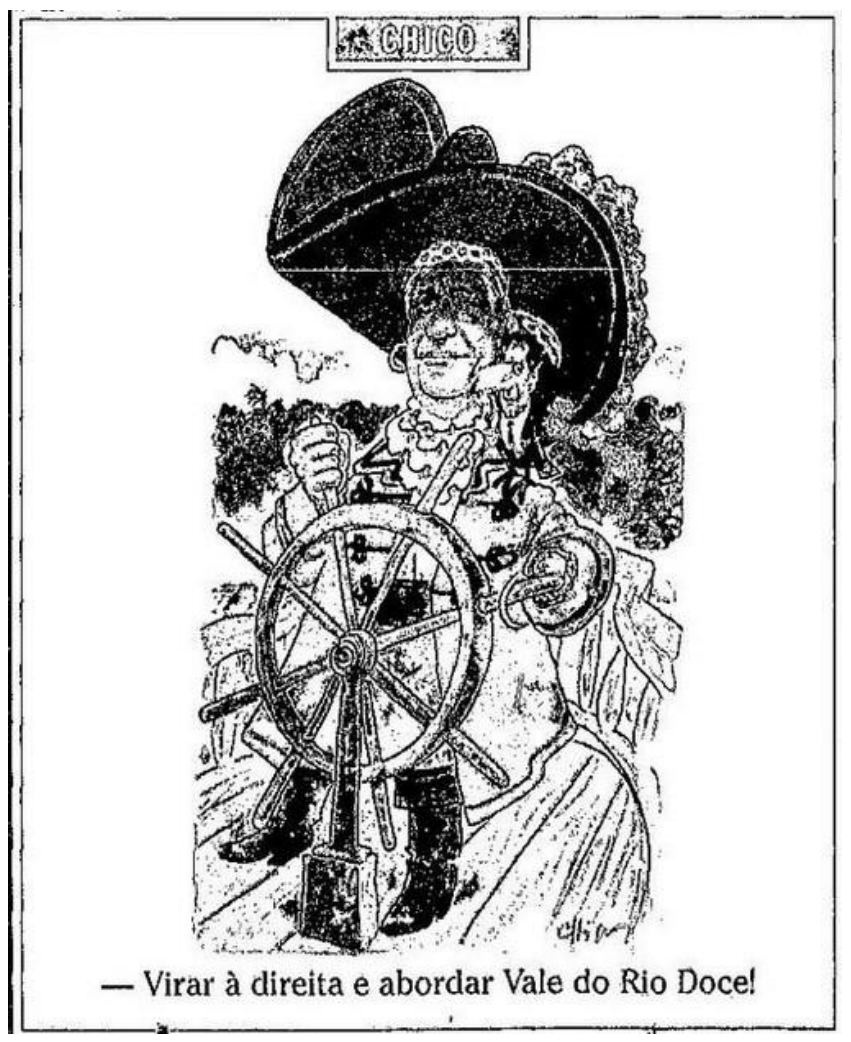

Fonte: $O$ Globo. 05.06.1996. www.acervo.oglobo.com.br

O uso da metáfora de um navio para representar o país e o presidente como o comandante da embarcação se tornou um recurso tradicional na história da caricatura brasileira. FHC, na figura 07, está caracterizado por roupas e acessórios de pirata, com um tucano no ombro esquerdo, identificado como o economista Pérsio Arida, filiado ao PSDB também, com o nariz ampliado para se parecer com a ave símbolo do partido. Arida, expresidente do Banco Central, na época da privatização da Vale do Rio Doce ${ }^{8}$ atuava em um

\footnotetext{
${ }^{8}$ A Vale é uma empresa multinacional brasileira e uma das maiores mineradoras do mundo. Foi criada em 1942 no governo de Getúlio Vargas, para a exploração das minas de ferro na região de Itabira, no estado de Minas Gerais. A charge se refere ao período de venda da estatal, em maio de 1997, durante o governo de FHC, com
} 
fundo de investimentos privado e foi consultor no processo movido por FHC. O enunciado verbal também supõe um posicionamento político, pois direita é a linha de atuação de FHC, dentro de um projeto neoliberal que defende a privatização, alegando que investidores externos têm melhores condições de alavancar os setores. O fato de ser um navio pirata é extremamente significativo, pois constrói a associação com saques e pilhagens.

A charge da figura 08 ironiza os rumos tomados por Lula, sugerindo um posicionamento mais próximo dos interesses econômicos das classes dominantes, dos projetos da direita neoliberal.

Figura 08: Chico Caruso. Pilotando o transatlântico

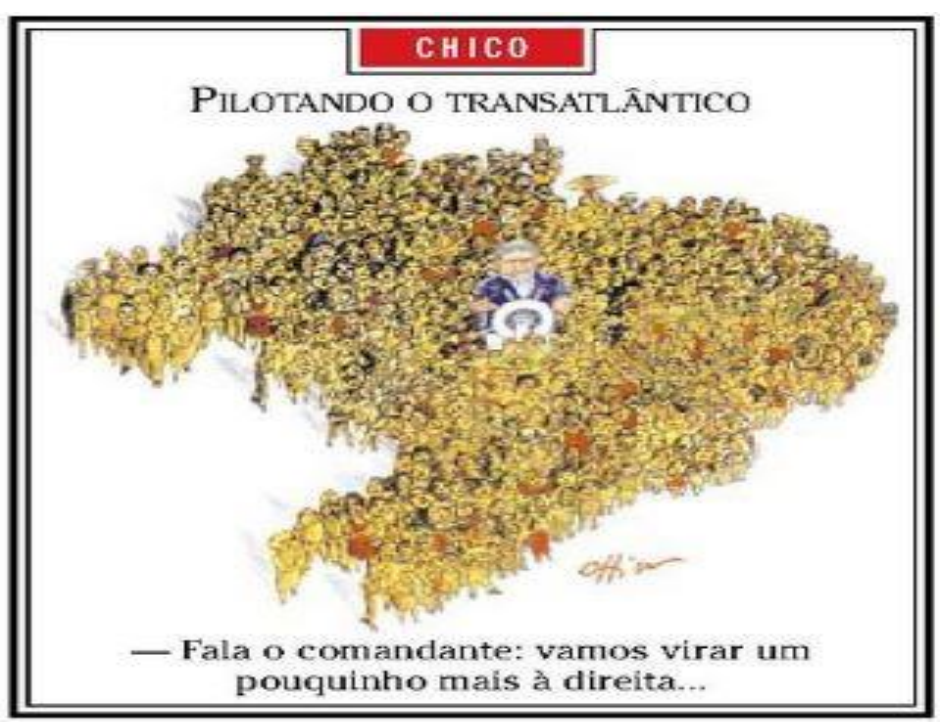

Fonte: $O$ Globo. 17.02.2003. www.acervo.oglobo.com.br

No dia 12 de fevereiro de 2003, em Brasília, Lula discursa para defender uma mudança de rumo lenta e segura na política econômica e usa muitas metáforas para comparar o país com um navio: “O Brasil não é um fusquinha, que pode dar um cavalo-de-pau, é um transatlântico. Se a virada não for feita aos poucos, pode afundar. E nós não temos vocação para Titanic" (O Globo, 12.02.2003). Foi neste contexto que, cinco dias mais tarde, foi

financiamento subsidiado, disponibilizado aos compradores pelo BNDES (Banco Nacional de Desenvolvimento Econômico e Social). Diversos relatos indicam que houve subvalorização da companhia. Relatórios indicam que em maio de 1995 a Vale informou à Securities and Exchange Comission, entidade que fiscaliza o mercado acionário dos Estados Unidos, que as reservas de minério de ferro em Minas Gerais eram de 7.918 bilhões de toneladas, mas, dois anos depois, o edital de privatização indicava apenas 1.4 bilhões de toneladas (AMAURY, 2012). Atualmente a Vale é uma empresa privada, de capital aberto, com sede no Rio de Janeiro. 
publicada esta charge. O foco da crítica apontava para as medidas que colocavam Lula como um governo de continuidade do antecessor, FHC. O mapa do Brasil aparece como um transatlântico e Lula assume o timão, anunciando novo rumo: “- Fala o comandante: vamos virar um pouquinho mais à direita". Na época, o presidente Lula tentava tranquilizar os aliados dizendo que precisava acalmar o mercado internacional para governar. O presidente do Banco Central, Henrique Meirelles, era o principal ponto de discórdia com esses aliados, já que mantinha a política econômica do governo neoliberal do PSDB (MATTEI; MAGALHÃES, 2010).

Figura 09: Chico Caruso. "Enquanto isso, na nossa zona de lançamentos".

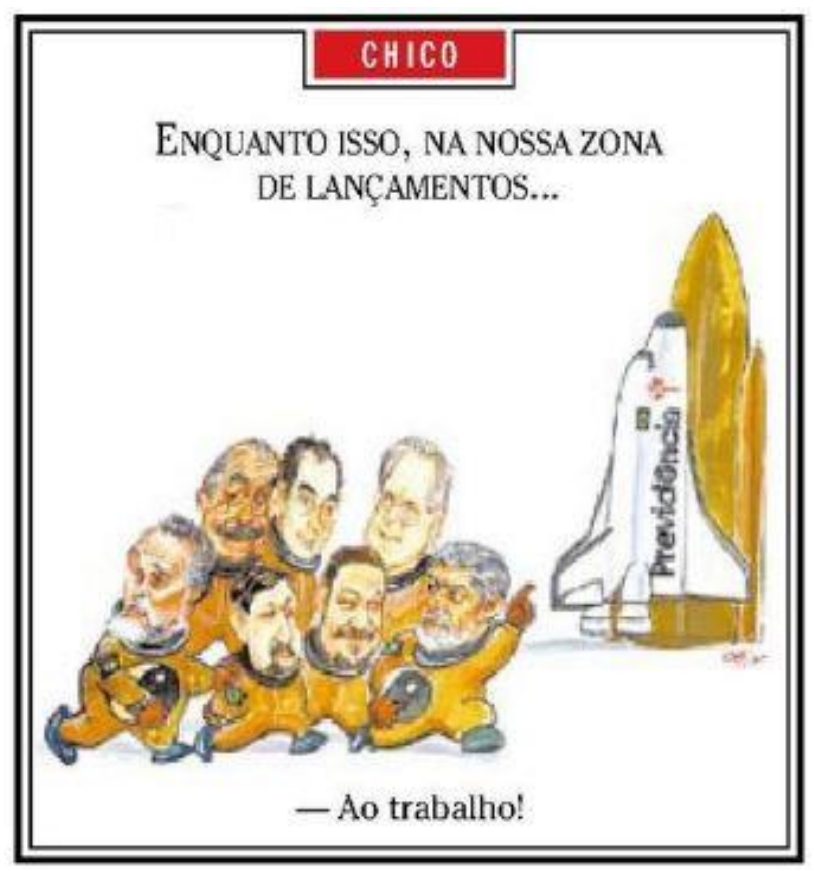

Fonte: O Globo. 04.02.2003. www.acervo.oglobo.com.br

Um bom exemplo de intertextualidade e citação de outros fatos jornalísticos está na cena em que Lula comanda uma equipe prestes a decolar para uma viagem espacial (figura 09), indicada pelas roupas de astronautas e pela posição da aeronave ao fundo. É possível identificar os ministros: Antônio Palocci, da Fazenda; Ricardo Berzoini, então ministro da Previdência Social; José Genoíno, deputado federal; José Dirceu, chefe da Casa Civil; João Paulo Cunha, presidente da Câmara Federal e José Sarney, presidente do Senado. Pela presença do ministro e pela nominação no foguete, o tema seria a Reforma da Previdência, Fronteiras: Revista de História | Dourados, MS | v. 20 | n. 36 | p. 12 - 37 | Jul. / Dez. 2018 
prestes a andar no Congresso Nacional, hipótese reforçada pela presença dos presidentes da Câmara e do Senado. O chargista, além de ironizar a plataforma de lançamentos com a presença dos políticos, pontua o que acontece na "nossa zona de lançamentos". A palavra zona costuma ser usada para identificar um território sem lei, no jargão popular brasileiro, onde tudo está bagunçado.

E o tom de crítica vai além dessas descrições, ganhando novas camadas de significado. Dias antes da charge, o ônibus espacial Columbia havia explodido e matado sete astronautas. A NASA suspendera os trabalhos no dia anterior, enquanto a investigação não esclarecesse o que teria levado à trágica explosão. O desenhista parece sugerir que a equipe econômica de Lula poderia explodir no ar, como o ônibus espacial ou ainda poderia estar prevendo uma grande catástrofe com a reforma proposta nesta gestão. A reforma previdenciária não foi aprovada na totalidade e o problema alegado no sistema não foi equacionado, segundo Mattei; Magalhães (2010).

Uma estratégia recorrente do humor gráfico pesquisado é o uso de charges sequenciadas, propondo narrativas a serem acompanhadas na leitura diária do jornal. Se o leitor perdesse uma das peças, precisaria recorrer aos conhecimentos prévios sobre o assunto através de outras fontes de informação. Ou a leitura seria um pouco distante da intenção do desenhista, talvez um pouco incompleta. Esse recurso do uso de imagens publicadas em uma sequência diária, inspirado nos quadrinhos e nas tiras de ação e aventuras, pressupõe um leitor atento e fiel ao periódico.

FHC teve diversas confusões políticas relacionadas à desregulamentação bancária. Esse universo da política brasileira foi representado por Chico Caruso como um ringue, uma luta de boxe. Antônio Carlos Magalhães (ACM), então senador, Defendia o fim da intervenção do Banco Central na instituição bancária baiana. o Banco Econômico. Este foi acusado nos relatórios do Banco Central por maquiagem contábil na instituição e desvios de dinheiro do banco para os gestores. Além disso, era o banco mais antigo do Brasil e foi criado como banco público e, durante as medidas de ajuda de FHC, foi incorporado pela iniciativa privada (ALVES, 2003). 
Fronteiras: Revista de História

Representações humorísticas de FHC e de Lula no jornal O Globo (1995-2010)

Marilda Lopes Pinheiro Queluz; Ligia Carla Gabrielli Berto

Figura 10: Chico Caruso

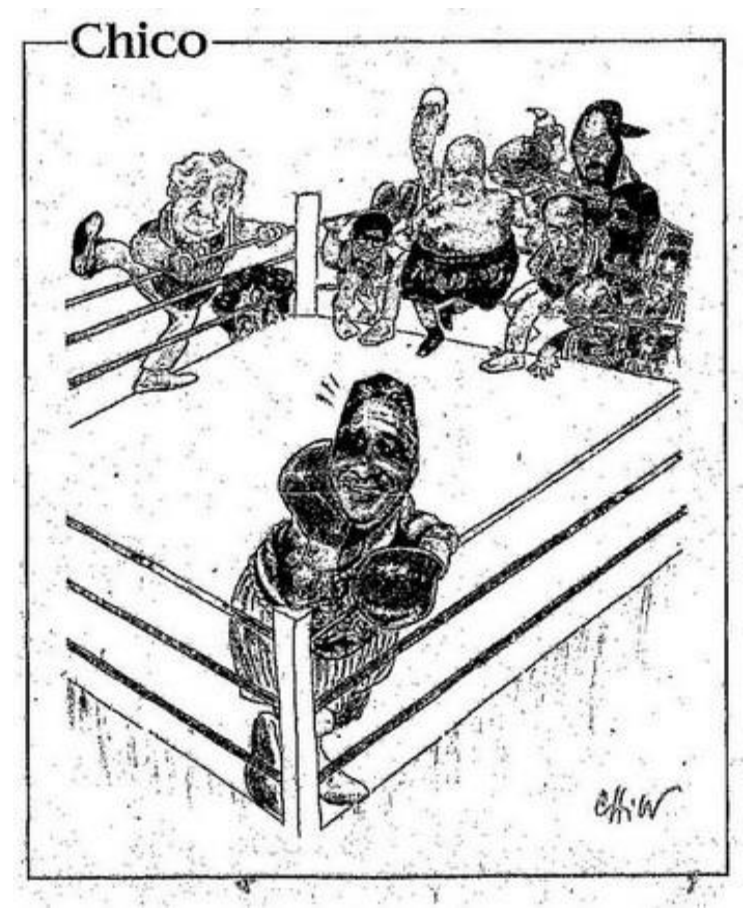

Fonte: $O$ Globo. 24.08.1995. www.acervo.oglobo.com.br

Na figura 10, vemos FHC no canto oposto do ringue, esperando para enfrentar ACM. A crítica foi focada em FHC porque no dia anterior a bancada de parlamentares da Bahia havia se reunido com representantes do governo federal para possibilitar que os correntistas do Banco Econômico tivessem acesso aos valores que possuíam depositados na instituição. $\mathrm{O}$ Banco Central havia fixado em $\mathrm{R} \$ 5.000,00$ o limite de saques dos investidores, o que gerou grande repercussão negativa no estado da Bahia, por isso, as ações contra as medidas do governo FHC estavam centralizadas na figura do senador ACM, ex-governador da Bahia. FHC se mostra bastante tranquilo, esboçando um sorriso enigmático, com um certo desprezo pela pressão política, imposta pelas medidas anunciadas para o setor. 
Figura 11: Aroeira

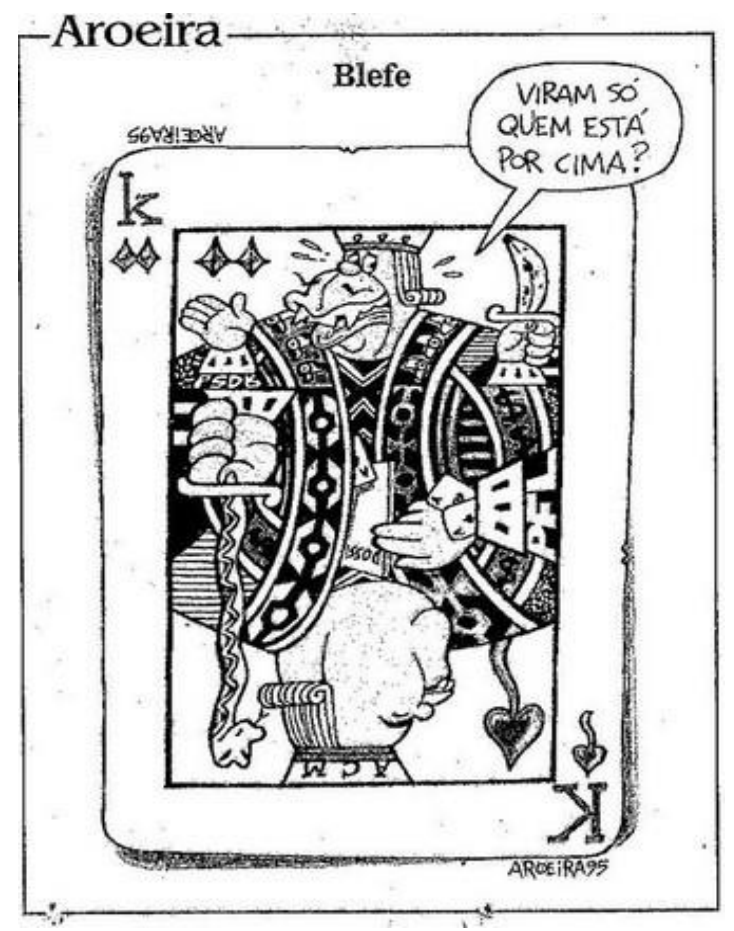

Fonte: $O$ Globo. 19.08.1995. www.acervo.oglobo.com.br

A analogia criada pela charge da figura 11 é que a política é um jogo de cartas marcadas. FHC tinha intenção de privatizar bancos e encontrou forte resistência do governo da Bahia. O título da charge indica que alguém está blefando, ou mesmo ambos poderiam estar faltando com a verdade, já que blefe é um termo usado para indicar que um dos jogadores pressiona mesmo sob suspeição de não poder ganhar a partida. FHC e ACM ilustram a carta, representada pelo K, que é o naipe do rei, a segunda carta mais valiosa de um baralho. Nos detalhes, FHC parece blefar ao afirmar "viram só quem está por cima", dando a entender que ele estaria ganhando um jogo que a imprensa noticiava como crítico e sem ganhador e que prejudicava principalmente os correntistas do Banco Econômico, eleitores de ACM. Além do mais, as gotículas que saem do seu rosto expressam a preocupação do caricaturizado. No dia desta publicação, os jornais divulgaram o teor de uma conversa entre ACM, senador pela Bahia e FHC, na qual, segundo os jornais, o presidente disse ao senador que não poderia ajudar o banco baiano para não ficar desmoralizado. Tal situação foi ironizada por Aroeira na imagem ao colocá-lo segurando uma banana. ACM havia pedido para que o Banco Central fizesse repasses de dinheiro para salvar o banco e evitar o 
fechamento e o bloqueio de contas. É ele que está representado na parte de baixo da carta, empunhando uma espada em formato de cobra, que também pode representar um possível golpe traiçoeiro do senador. Outros elementos simbólicos ampliam as camadas de sentidos do diálogo, como os naipes usados para cada um deles. FHC tem naipe de ouros, que no baralho é representado por Júlio César, general e ditador romano que morreu assassinado por membros do Senado, em 44 a.C., detalhe que pode estabelecer uma associação com o cargo de ACM. O lado em que está o senador é representado pelo rei de espadas. Esta carta no baralho é associada ao rei hebreu Davi, cujos relatos bíblicos indicam que ele foi um líder reunificador de Israel, o que poderia ser ainda uma paródia com a proposta de defesa de ACM aos baianos. O manto de ACM está marcado pelo símbolo do Banco Econômico e ambas as vestes estampam o cifrão que representa o dinheiro em espécie.

Figura 12: Aroeira. "Proer- Mater"

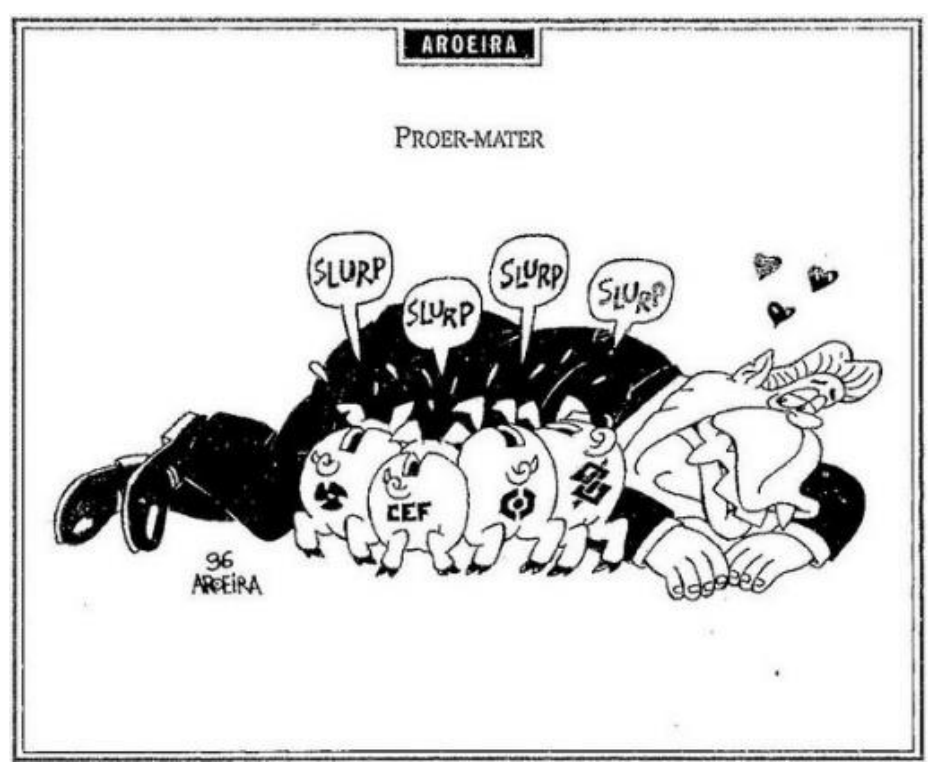

Fonte: $O$ Globo. 12.05.1996. www.acervo.oglobo.com.br

$\mathrm{Na}$ figura 12, retoma-se uma outra metáfora usual nas charges políticas e econômicas, a ideia de políticos mamarem nas tetas do governo. Aroeira representou os bancos como porquinhos mamando nas "tetas" de FHC. Vale lembrar que, na época, eram comuns os cofrinhos em formato de porcos, um símbolo popular de poupança. Os logotipos dos bancos nominam alguns daqueles que foram beneficiados pelo pacote do governo: Banco 
Nacional, Caixa Econômica Federal, Banco Econômico e Banco do Brasil. FHC, apesar de aparecer em uma posição nada convencional e de se trajar de maneira elegante, tem os traços do rosto bem exagerados e grotescos. Os corações acima da cabeça sugerem o afeto maternal, reiterando visualmente a sátira presente no título "Proer-Mater", unindo a palavra mater (do latim, mãe) ao Programa de Estímulo à Reestruturação e ao Fortalecimento do Sistema Financeiro Nacional (Proer), que concedia uma linha especial de assistência financeira destinada a permitir reorganizações societárias no sistema, a um baixo custo (estimado em 1 a $2 \%$ do PIB). O programa foi considerado um presente, pois foram gastos $\mathrm{R} \$ 37,76$ bilhões com os bancos em funcionamento no país, valor que consta no relatório da CPI dos Bancos, do Senado Federal (GIAMBIAGI, 2011).

Outra mensagem que pode ser interpretada aqui está relacionada ao ambiente onde se criam os porcos, animais que vivem na lama, na sujeira, cujo efeito simbólico cola-se à atitude política: salvar os bancos, sistemas financeiros altamente individualistas e capitalistas, em detrimento do uso de recursos para fins sociais, por exemplo.

Figura 13: Chico Caruso. "E no circo Brasil"

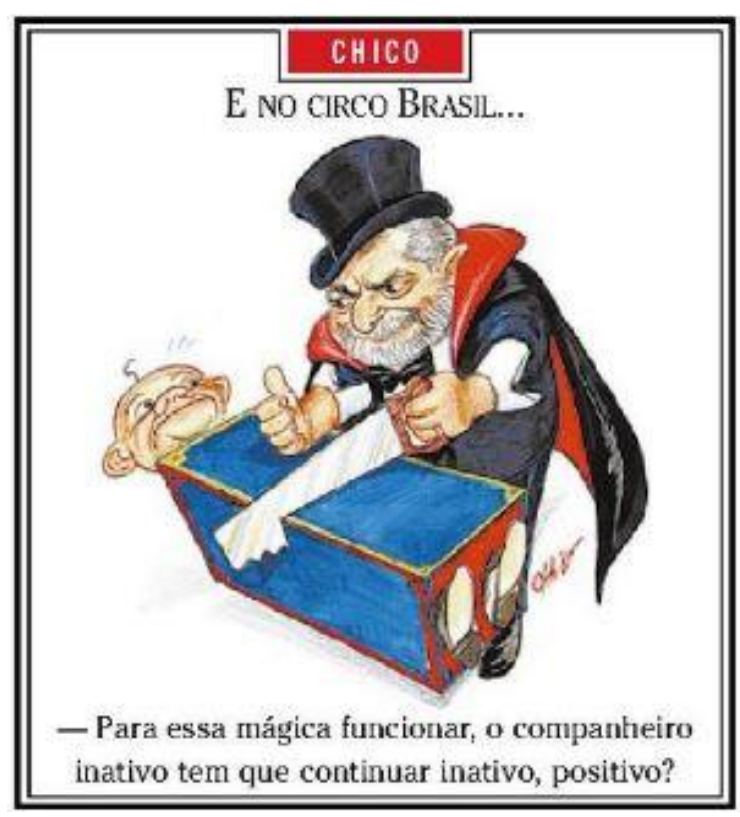

Fonte: $O$ Globo. 12.05.2003. www.acervo.oglobo.com.br

Chico Caruso usou a metáfora do circo para representar o país durante alguns episódios do governo Lula. Na figura 13, o presidente Lula é um mágico, identificado pela Fronteiras: Revista de História | Dourados, MS | v. 20 | n. 36 | p. 12 - 37 | Jul. / Dez. 2018 
capa e chapéu típicos das apresentações circenses. O chargista nos remete à discussão política do momento, a Reforma da Previdência que previa, entre outras medidas, a taxação dos servidores públicos aposentados. O famoso número de mágica, de serrar ao meio uma pessoa, ironiza o corte no benefício do trabalhador aposentado, associado metaforicamente ao termo inativo.

A taxação dos inativos teve um forte conteúdo simbólico, pela ideia de que o Brasil estaria enfrentando um velho "tabu", uma tentativa que havia sido feita no governo FHC, inclusive por imposição colocada em acordo com o FMI, como forma de aumentar o fluxo de recursos internos do Brasil. Na época, foi julgada inconstitucional pelo Supremo Tribunal Federal, mas, ao ser resgatada em 2003, enfrentava fortes críticas já que Lula sempre foi reconhecido como defensor dos direitos dos trabalhadores (GIAMBIAGI, 2011).

Figura 14: Chico Caruso. "Ainda no circo Brasil"

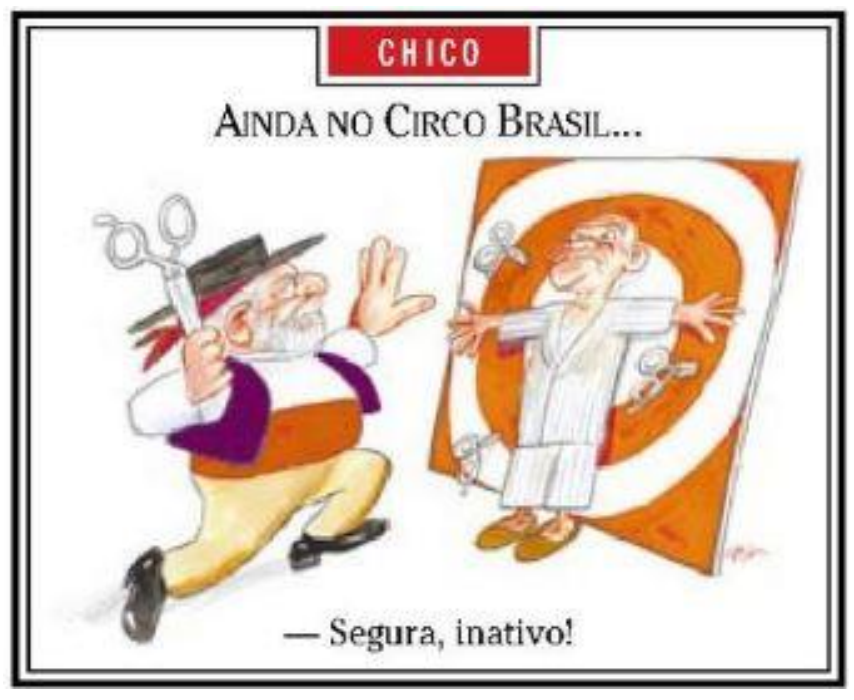

Fonte: O Globo. 16.05.2003. www.acervo.oglobo.com.br

A expressão inativo e as manobras do presidente Lula continuam no foco da crítica. Na figura 14, Chico Caruso ironiza o famoso número circense do atirador de facas, colocando Lula como protagonista e substituindo as facas por tesouras, símbolo dos cortes nos gastos públicos. Vestido como uma espécie de Zorro, Lula está na eminência de lançar uma tesoura e pede que o homem ao centro do alvo, que representa um aposentado, fique parado. A 
caracterização do aposentado merece destaque: magro, calvo, usando pijamas, estereótipo de alguém que não teria muito o que fazer, diante da situação ou das circunstâncias da vida.

Outra metáfora usada de modo recorrente no humor gráfico brasileiro é o jogo de futebol, representando tanto a política como a economia. O primeiro semestre de 2008, por exemplo, foi um período difícil para conter a inflação. Nos seis primeiros meses do ano nenhuma aplicação para rendimentos conseguiu superar o índice inflacionário e isso virou tema de muitas charges. Chico Caruso se valeu de uma sequência narrativa para interpretar a preocupação do governo com o assunto.

Figura 15: Chico Caruso

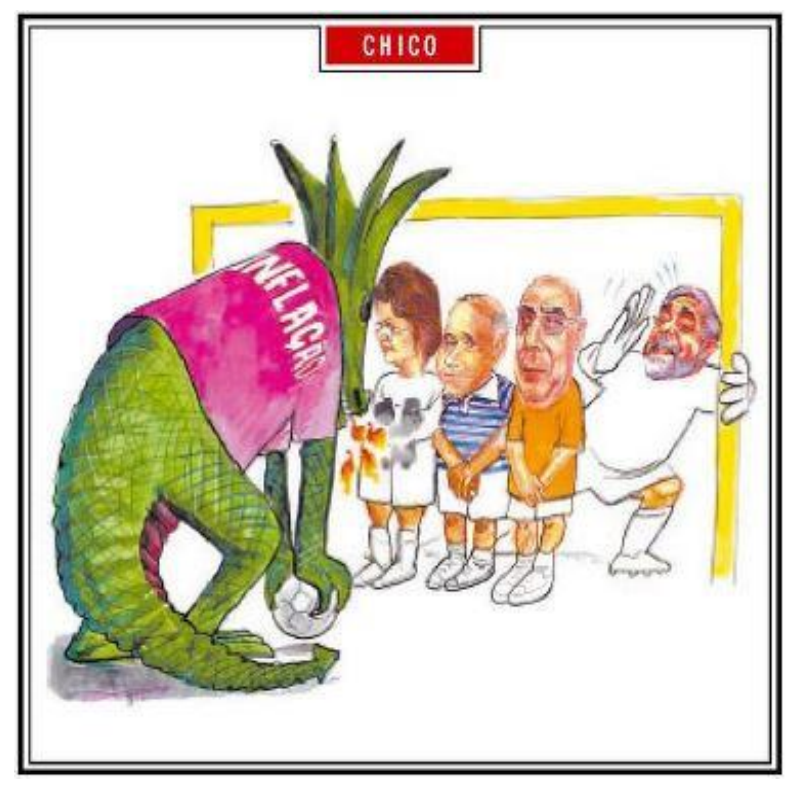

Fonte: $O$ Globo. 01.07.2008. www.acervo.oglobo.com.br

A figura 15 mostra um jogo de futebol, cujo lance se resume à cobrança de uma falta. Lula é o goleiro e, na barreira, para ajudar na defesa estão: Dilma Roussef, então chefe da Casa Civil, Guido Mantega, ministro da Fazenda e Henrique Meirelles, presidente do Banco Central. O chute será dado por um dragão, símbolo tradicional da inflação. Pressionada, a equipe de governo se vê diante de uma situação difícil, dependendo muito da sorte, tal qual um momento decisivo de uma partida de futebol.

No dia seguinte, o assunto persiste e a barreira incorpora outro personagem, o ministro do Planejamento, Paulo Bernardo, que tem o tamanho corporal aumentado para 
tentar fechar a trave e diminuir a chance de gol da inflação, o monstro que aterrorizava os planos econômicos e as metas de desenvolvimento.

A leitura desta sequência de charges, mais uma vez, pode ser outra, caso o leitor não seja assíduo e não acompanhe as notícias diárias. A charge estampou a capa de O Globo no dia 01 de julho de 2008, e acompanhava a principal manchete do dia: "Inflação derrota todas as aplicações do ano", reportagem que, aliás, era bastante crítica à atuação do governo federal, que estava em campanha para eleger um sucessor de Lula.

\section{CONSIDERAÇÕES FINAIS}

A repetição metafórica é um recurso fundamental da caricatura e da charge, como forma de expressar dimensões inimagináveis em comparações corriqueiras, bem humoradas e críticas do enredo em que se consolidam as mais importantes decisões políticas. Consegue-se, através das mensagens metafóricas, demonstrar com mais habilidade e rapidez os valores culturais inscritos nos objetos, cenas e personagens, compartilhando repertórios que fazem parte do cotidiano.

[...] os signos são intrinsicamente sociais, isto é, são criados e interpretados no interior dos complexos e variados processos que caracterizam o intercâmbio social. Os signos emergem e significam no interior de relações sociais, estão entre seres socialmente organizados: não podem, assim, ser concebidos como resultantes de processos apenas fisiológicos e psicológicos de um indivíduo isolado (FARACO, 2003, p. 48).

Na interpretação e na crítica dos acontecimentos da política brasileira os desenhistas buscaram inspiração e referências na arte, no cinema, nos fatos jornalísticos e na própria história da caricatura. Nas estratégias discursivas criadas por Aroeira e, principalmente, por Chico Caruso, percebe-se um diálogo entre a caricatura dos políticos e a linguagem das charges, o uso de metáforas visuais, paródias, intertextualidade e citações, e até mesmo narrativas sequenciadas dos quadrinhos. O humor gráfico de ambos pede um leitor assíduo do jornal, atento às notícias e aos fatos econômicos e políticos. Observa-se nos desenhos de Aroeira um investimento maior no exagero e na deformação dos traços para representar FHC, além de uma crítica mais ácida a sua atuação política, presente na associação paródica com o Zé do Caixão e com o gorila King Kong, e da metáfora da mãe que amamenta/financia os 
porquinhos/bancos. Chico Caruso, por sua vez, aposta na semelhança quase realista dos personagens e em um rico repertório de imagens metafóricas e vários níveis de intertextualidade, representando FHC quase sempre fazendo pose, em negociação com outros políticos e Lula em situações dinâmicas, cômicas e atrapalhadas.

Algumas metáforas são bastante recorrentes nas diversas maneiras de representar o país como a do navio, por exemplo, cujo rumo é dado por um comandante/presidente a serviço dos interesses econômicos das classes dominantes. Nas charges analisadas aqui, a política é representada como um espaço de tensões e disputas, um lance de uma partida de futebol, um jogo de cartas marcadas, como o ringue de uma luta de boxe. O Brasil é visto pejorativamente como um abacaxi, como um circo, como uma nau em constante mudança de direção, tendendo um pouquinho mais para a direita. Embora as charges não desafiem ou entrem em contradição com o posicionamento conservador de $O$ Globo, as cenas demarcam uma simbologia escrachada que, na maioria das vezes, não faz o leitor rir, mas o desloca de seu ponto de vista e o leva a refletir sobre os acontecimentos, construindo novos significados entre o que foi noticiado e a opinião dos desenhistas.

\section{REFERÊNCIAS}

ALVES, Giovanni. Limites do sindicalismo - Marx, Engels e a crítica da economia política. São Paulo: Editora Praxis, 2003.

ALVES, Giovanni. Trabalho e Neodesenvolvimentismo: Choque de capitalismo e nova degradação do trabalho no Brasil. São Paulo: Editora Praxis, 2014.

BAKHTIN, Mikhail. Estética da criação verbal. São Paulo: Martins Fontes, 2003.

CHARTIER, Roger. História Cultural. Lisboa: Difel; Bertrand do Brasil, 1988.

FARACO, Carlos Alberto. Linguagem e Diálogo: as ideias linguista do círculo de Bakhtin. Curitiba: Criar Edições, 2003.

FARTHING, S. Tudo sobre arte. Rio de Janeiro: Sextante, 2011.

FIORIN, José Luiz. Introdução ao pensamento de Bakhtin. São Paulo: Ática, 2006.

FONSECA, Joaquim da. Caricatura a imagem gráfica do humor. Porto Alegre: Artes e Ofícios, 1999. 
GIAMBIAGI, Fábio (org.). Economia Brasileira Contemporânea 1945-2010. Rio de Janeiro: Elsevier, 2011.

GIANNOTTI, Vito. História das lutas dos tabalhadores no Brasil. Rio de Janeiro: Mauad X, 2007.

KATZ, Cláudio. Neoliberalismo, neodesenvolvimentismo, socialismo. São Paulo: Editora Expressão Popula, 2016.

LAGO, Pedro Corrêa do. Caricaturistas brasileiros 1836-1999. Rio de Janeiro: Sextante, 1999.

LEMOS, Renato (org.). Uma história do Brasil através da caricatura 1840-2001. Rio de Janeiro: Bom Texto, Letras e Expressões, 2001.

LIMA, Herman. História da Caricatura no Brasil. Rio de Janeiro. Vol.: I, II, III e VI: José Olympio Editora, 1963.

MAGNO, Luciano. História da caricatura brasileira. Rio de Janeiro: Gala Edições de Arte, 2012.

MATTEI, Lauro; MAGALHÃES, Luis Felipe. A política econômica durante o governo Lula (2003-2010): cenários, resultados e perspectivas. P. 135 - 151. (2010). Disponível em:

http://br.boell.org/sites/default/files/downloads/Livro_Lula_Internet_9.pdf. Acesso em: 20 ago. 2016.

MOTTA, Rodrigo Patto Sá. Jango e o golpe de 1964 na caricatura. Rio de Janeiro: Jorge Zahar, 2006.

RIANI, Camilo. Tá rindo de quêe? São Paulo: Editora Unimep, 2002.

ROMUALDO, Edson Carlos. Charge jornalística: intertextualidade e polifonia um estudo de charges da Folha de S. Paulo. Maringá: Eduem, 2000.

SALIBA, Elias Thomé. Raízes do riso. A representação humorística na história brasileira: da Belle Époque aos primeiros tempos do rádio. São Paulo: Companhia das Letras, 2002

Recebido em: 30/05/2018 Aprovado em: 23/08/2018 